\title{
PENGARUH KEMAMPUAN, SIKAP, KEINGINAN YANG DIPERSEPSIKAN, DAN NORMA SUBJEKTIF TERHADAP INTENSI BERWIRAUSAHA
}

\author{
Albert Jayaantara Kusuma ${ }^{1}$, Oey Hannes Widjaja² \\ ${ }^{1}$ Program Studi Manajemen, Fakultas Ekonomi dan Bisnis, Universitas Tarumanagara Jakarta \\ Email: albert.jk97@gmail.com \\ ${ }^{2}$ Program Studi Manajemen, Fakultas Ekonomi dan Bisnis, Universitas Tarumanagara Jakarta* \\ Email: hannesw@fe.untar.ac.id \\ *Penulis Korespondensi
}

Masuk : 02-08-2021, revisi: 15-08-2021, diterima untuk diterbitkan : 30-08-2021

\begin{abstract}
ABSTRAK
Tujuan dari penelitian ini untuk menguji dan menganalisis pengaruh kemampuan berwirausaha, sikap berwirausaha, keinginan yang dipersepsikan, dan norma subjektif terhadap intensi berwirausaha mahasiswa Universitas Tarumanagara dengan populasi 100 orang. Pengerjaan yang digunakan dalam metode penelitian ini adalah Metode quantity (kuantitatif) dengan alat analisis Partial Least Square. Hasil penelitian ini didapat bahwa yang berpengaruh terhadap intensi berwirausaha adalah kemampuan, keinginan, dan sikap.
\end{abstract}

Kata Kunci: kemampuan berwirausaha, sikap berwirausaha, keinginan yang dipersepsikan, norma subjektif, intensi berwirausaha

\section{ABSTRACT}

The purpose of this study was to examine and analyze the influence of entrepreneurial abilities, entrepreneurial attitudes, perceived desires, and subjective norms on entrepreneurship intention of Tarumanagara University students with a population of 100 people. The workmanship used in this research method is the quantity method (quantitative) with Partial Least Square analysis tools. The results of this study indicate that the ones that influence entrepreneurial intentions are the ability, perceived desire, and attitude.

Keywords: entrepreneurial abilities, entrepreneurial attitudes, perceived desires, subjective norms, entrepreneurship intention

\section{PENDAHULUAN}

\section{Latar belakang}

Pertumbuhan jumlah tenaga kerja terus meningkat. Meningkatnya jumlah tenaga kerja kurang diimbangi dengan ketersediaan lapangan kerja. Oleh karena melimpahnya pencari kerja dan sedikitnya lowongan kerja, perusahaan yang membutuhkan karyawan cenderung menetapkan standar kualitas sumber daya manusia yang cukup tinggi. Kualitas sumber daya manusia menentukan keberhasilan kerja dan perolehan pekerjaan. Berdasarkan permasalahan tersebut maka pengembangan sikap wirausaha sangat diperlukan dalam menanggapi kurangnya lapangan pekerjaan. Seorang wirausahawan diharapkan mampu membuka lapangan pekerjaan bagi orang lain. Manfaat ini diharapkan mampu menekan laju pengangguran di Indonesia.

Suatu negara mungkin kaya dalam sumber daya material dan modal, tetapi jika kewirausahaan kurang, pemanfaatan sumber daya menjadi tidak akan seperti yang diharapkan. Para pengusaha 
adalah bagian dari masyarakat industri dan dengan demikian pengusaha dianggap sebagai aset. Pengusaha bertanggung jawab tidak hanya untuk mata pencaharian sendiri, tetapi juga untuk menciptakan lapangan kerja bagi orang lain. Kewirausahaan dapat digunakan sebagai salah satu faktor kunci dalam pembangunan ekonomi. Kesempatan ini merupakan potensi yang cukup besar bagi mahasiswa untuk berkiprah di sektor usaha atau sebagai pebisnis.

Istilah kewirausahaan kata dasarnya berasal dari terjemahan entrepreneur yang dalam bahasa Inggris dikenal dengan arti between taker atau go-between (Yousaf et al., 2015). Pada pertengahan istilah "entrepeneur" digunakan untuk menggambarkan seorang aktor sebagai orang yang memimpin proyek produksi. Wirausaha dinyatakan oleh Buchari (2007) adalah orang yang mendobrak sistem ekonomi yang ada dengan memperkenalkan barang dan jasa yang baru, dengan menciptakan bentuk organisasi baru atau mengolah bahan baku baru. Orang tersebut melakukan kegiatannya melalui organisasi bisnis yang baru ataupun yang telah ada. Dalam definisi tersebut, ditekankan bahwa wirausaha adalah orang yang melihat adanya peluang kemudian menciptakan sebuah organisasi untuk memanfaatkan peluang tersebut.

Studi mengenai kewirausahaan merupakan studi yang sangat penting dan menarik. Studi ini umumnya mencoba mencari faktor-faktor yang mempengaruhi pembentukan seorang wirausahawan (Widjaya et al., 2014). Seorang wirausahawan merupakan seorang yang penuh dengan pemikiran yang luas, tekad yang kuat dan keberanian yang tinggi. Wirausaha adalah orang yang mendobrak sistem ekonomi yang ada dengan memperkenalkan barang dan jasa yang baru, dengan menciptakan bentuk organisasi baru atau mengolah bahan baku baru. Orang tersebut melakukan kegiatannya melalui organisasi bisnis yang baru ataupun yang telah ada. Dalam definisi tersebut, ditekankan bahwa wirausaha adalah orang yang melihat adanya peluang kemudian menciptakan sebuah organisasi untuk memanfaatkan peluang tersebut. Studi mengenai kewirausahaan berarti studi yang membahas faktor-faktor yang membentuk manusia yang memiliki sifat tersebut. Tidak mudah membentuk manusia untuk memiliki sifat kewirausahaan karena tiap orang memiliki karakteristik yang berbeda.

Fenomena yang terjadi pada umumnya para mahasiswa lebih memilih bekerja pada suatu perusahaan dibandingkan menjadi seorang wirausaha. Kesempatan bagi mahasiswa untuk terlibat dalam bidang kewirausahaan terbuka sangat besar. Sebaiknya, kesempatan ini diambil oleh mahasiswa, sehingga dapat menciptakan lapangan kerja. Oleh karena itu, perlu dianalisis faktor yang mempengaruhi intensi berwirausaha mahasiswa.

Intensi berwirausaha sangat dibutuhkan untuk membentuk seorang wirausaha yang sukses dan pantang menyerah. Intensi berwirausaha dapat membantu seseorang agar berperilaku dan fokus terhadap tujuan berwirausaha, sehingga berdampak kepada kesuksesan berwirausaha. Intensi berwirausaha merupakan dasar bagi wirausaha untuk dapat menjalankan usaha yang didirikannya. Seorang wirausaha harus memiliki intensi berwirausaha yang tinggi agar dapat berwirausaha dengan sukses. Menurut Krishna (2013), intensi berwirausaha adalah penentu wirausaha untuk memperoleh semangat kewirausahaan dalam tindakan.

Kewirausahaan sejatinya merupakan pilihan yang tepat bagi setiap individu yang termotivasi untuk menciptakan lapangan pekerjaaan, bukan hanya mencari kerja. Intensi berwirausaha berperan penting untuk membentuk individu menjadi seorang entrepreneur, sedangkan intensi berwirausaha sendiri dipengaruhi oleh banyak faktor (Widjaya dan Ekawati, 2017). Untuk mengembangkan semangat berwirausaha mahasiswa, hal yang perlu dilakukan adalah mengidentifikasi faktor-faktor yang mempengaruhi intensi berwirausaha. Penelitian ini mencoba 
mengaitkan theory of planned behavior dalam mencari faktor-faktor yang mempengaruhi intensi berwirausaha. Theory of planned behavior didesain untuk menguji dan melakukan prediksi human intention dan actual behavior. Ketika seorang individu melakukan suatu perilaku tanpa adanya kontrol terhadap perilaku tersebut. Model theory of planned behavior dipengaruhi oleh dua faktor, yaitu pengaruh eksternal (external influences) dan pengaruh internal (internal influences). Pengaruh eksternal yang digunakan untuk memprediksi actual behavior adalah social influence: subjective norm, dan situational influence: perceived behavior control, sementara faktor internal yang digunakan untuk memprediksi actual behavior adalah personal influence: attitude.

Beberapa penelitian yang mencoba mengidentifikasi faktor-faktor yang mempengaruhi intensi berwirausaha adalah penelitian Yousaf et al. (2015), Malebana (2014), dan Robledo et al. (2015). Penelitian Yousaf et al. (2015) menyimpulkan bahwa terdapat pengaruh sikap berwirausaha, keinginan yang dipersepsikan, dan norma subjektif terhadap intensi berwirausaha, penelitian Malebana (2014) menyimpulkan bahwa terdapat pengaruh entrepreneurial intention, attitude toward becoming an entrepreneur, norma subjektif, entrepreneurial role model, social valuation of entrepreneurship, dan knowledge of entrepreneurial support terhadap motivasi berwirausaha. Sementara itu, penelitian Robledo et al., (2015) menyimpulkan bahwa kontrol perilaku dan sikap terhadap perilaku mempengaruhi niat kewirausahaan mahasiswa terhadap intensi kewirausahaan, sedangkan norma subjektif tidak. Selain itu, penelitian ini menunjukkan bahwa efek moderasi dari jenis kelamin memiliki pengaruh positif bagi perempuan dalam hubungan antara orang-orang norma subjektif dan kontrol perilaku yang dirasakan. Penelitian ini merupakan penelitian replikasi dari penelitian Yousaf et al. (2015). Menurut Yousaf et al. (2015), faktor yang mempengaruhi intensi berwirausaha adalah kemampuan berwirausaha, sikap berwirausaha, keinginan yang dipersepsikan, dan norma subjektif.

Menurut Yousaf et al. (2015), kemampuan berwirausaha adalah kemampuan mengenal peluang dari informasi yang tersedia. Kemampuan berwirausaha dapat memberikan kepercayaan diri kepada wirausahawan dalam hal mengelola usaha. Kemampuan berwirausaha dapat diperoleh melalui pendidikan dan pengalaman. Menurut Yousaf et al. (2015), wirausahawan yang memiliki kemampuan berwirausaha cenderung memiliki intensi berwirausaha yang tinggi.

Menurut Yogatama (2013), sikap adalah evaluasi dan kencenderungan seseorang yang relatif konsisten untuk bereaksi atau memberikan respon terhadap suatu objek sikap. Sikap menunjukkan tingkatan dimana seseorang mempunyai evaluasi yang baik atau kurang baik. Semakin baik sikap seseorang terhadap wirausaha, maka semakin tinggi intensi berwirausaha yang dimilikinya. Menurut Robledo et al. (2015), sikap berpengaruh terhadap intensi berwirausaha. Wirausaha menumbuhkan sikap yang mendukung keberhasilan berwirausaha. Sikap ini mengevaluasi tindakan yang mendukung dan tidak mendukung terhadap keberhasilan berwirausaha dengan tujuan meningkatkan intensi berwirausaha.

Menurut Yousaf et al. (2015), keinginan yang dipersepsikan adalah keinginan yang merupakan tingkat ketertarikan seseorang untuk memulai usahanya sendiri. Keinginan yang dipersepsikan adalah derajat ketertarikan seseorang untuk berwirausaha. Para wirausahawan umumnya memiliki keinginan yang dipersepsikan yang tinggi. Menurut Yousaf et al. (2015), keinginan yang dipersepsikan mempengaruhi intensi kewirausahaan. Keinginan yang dipersepsikan tinggi menggambarkan wirausahawan yang memiliki tingkat ketertarikan yang tinggi dalam berwirausaha. 
Yogatama (2013) mendefinisikan norma subjektif sebagai evaluasi seseorang mengenai tekanan sosial yang mempengaruhi individu untuk melakukan atau tidak melakukan suatu tindakan. Norma subjektif sebagai pengaruh sosial yang menunjukkan tekanan sosial yang dirasakan untuk melakukan atau tidak melakukan tindakan atau perilaku. Semakin tinggi dukungan dari norma subjektif terhadap kewirausahaan, maka semakin tinggi intensi berwirausaha. Menurut Robledo et al. (2015), norma subjektif berpengaruh terhadap intensi berwirausaha. Pengaruh lingkungan sosial sangat kuat dalam menentukan motivasi seseorang. Lingkungan sosial yang mendukung kewirausahaan dapat meningkatkan intensi berwirausaha.

Tujuan utama dari penelitian ini adalah untuk mengevaluasi pengaruh kemampuan berwirausaha, sikap berwirausaha, keinginan yang dipersepsikan, dan norma subjektif terhadap intensi berwirausaha.

\section{Kajian teori}

\section{Gambaran umum teori}

Teori perilaku terencana (theory of planned behavior) merupakan modifikasi atau pengembangan dari teori perilaku beralasan (theory of reason action). Inti teori ini tetap pada faktor minat berperilaku namun determinan minat tidak hanya sikap dan norma subyektif, melainkan menambahkan kontrol keperilakuan yang dirasakan. Kontrol keperilakuan yang dirasakan merupakan kondisi dimana orang percaya bahwa suatu tindakan itu mudah atau sulit dilakukan. Ini juga mencakup pengalaman masa lalu, disamping rintangan-rintangan yang ada yang dipertimbangkan orang tersebut (Robledo et al., 2015).

Sikap terhadap suatu perilaku dipengaruhi oleh keyakinan bahwa perilaku tersebut akan membawa kepada hasil yang diinginkan atau tidak diinginkan. Keyakinan mengenai perilaku apa yang bersifat normatif (yang diharapkan orang lain) dan motivasi untuk bertindak sesuai dengan harapan normatif tersebut membentuk norma subyektif dalam diri individu (Pratana \& Japarianto, 2014).

\section{Definisi Konseptual Variabel}

Menurut Andika dan Yuliana (2017), kemampuan berwirausaha adalah kesanggupan, kecakapan dan kekuatan dalam berwirausaha. Menurut Retno (2012), kemampuan wirausaha adalah keterampilan yang dimiliki oleh seorang wirausaha dalam memulai usaha dan mengelola usahanya yang di indikasikan dengan keberanian mengambil resiko, inisiatif \& proaktif, berorientasi pada prestasi, dan komitmen pada berbagai pihak, sementara menurut Yousaf et al. (2015), kemampuan berwirausaha adalah kemampuan mengenal peluang dari informasi yang tersedia.

Menurut Susanti dan Gunarsih (2008), sikap adalah tingkatan dimana seseorang mempunyai evaluasi yang baik atau kurang baik tentang perilaku tertentu. Sikap adalah perasaan individu positif atau negatif tentang melakukan suatu perilaku (Pratana \& Japarianto, 2014). Menurut Yogatama (2013), sikap adalah evaluasi dan kencenderungan seseorang yang relatif konsisten untuk bereaksi atau berespon terhadap suatu objek sikap.

Menurut Yousaf et al. (2015), keinginan yang dipersepsikan adalah keinginan yang merupakan tingkat ketertarikan seseorang untuk memulai usahanya sendiri. Menurut Ustha (2018), keinginan yang dipersepsikan adalah keinginan untuk melakukan sesuatu melalui ekspresi diri dan dengan kemandirian. Menurut Hendrawan dan Sirine (2017), keinginan yang dipersepsikan adalah kecenderungan hati dalam diri subjek untuk tertarik menciptakan suatu usaha yang 
kemudian mengorganisir, mengatur, menanggung risiko dan mengembangkan usaha yang diciptakannya tersebut.

Menurut Huda dkk. (2013), norma subjektif adalah persepsi atau asumsi seseorang mengenai harapan orang lain atas perilaku tertentu yang akan atau tidak dilakukan. Norma subjektif sebagai persepsi individu tentang apakah orang penting bagi individu berpikir perilaku harus dilakukan (Pratana \& Japarianto, 2014). Leo (2013) mendefinisikan norma subjektif sebagai evaluasi seseorang mengenai tekanan sosial yang mempengaruhi individu untuk melakukan atau tidak melakukan suatu tindakan.

Menurut Krishna (2013) intensi berwirausaha adalah: "the drive of an entrepreneur to maintain an entrepreneurial spirit in all their actions" yang artinya penentu wirausaha untuk memperoleh semangat kewirausahaan dalam tindakan. Menurut Ranmuthumalie (2010), intensi berwirausaha adalah "those motivate entrepreneurs to start their own business venture" yang artinya semua yang memotivasi wirausaha untuk memulai peluang bisnis. Intensi berwirausaha adalah " a state of mind directing and guiding the actions of individuals towards the development and implementation of new business concepts" yang artinya pemikiran yang mengarahkan dan membimbing tindakan individu menuju pengembangan dan implementasi konsep bisnis baru (Hattab, 2014).

\section{Hubungan antar variabel}

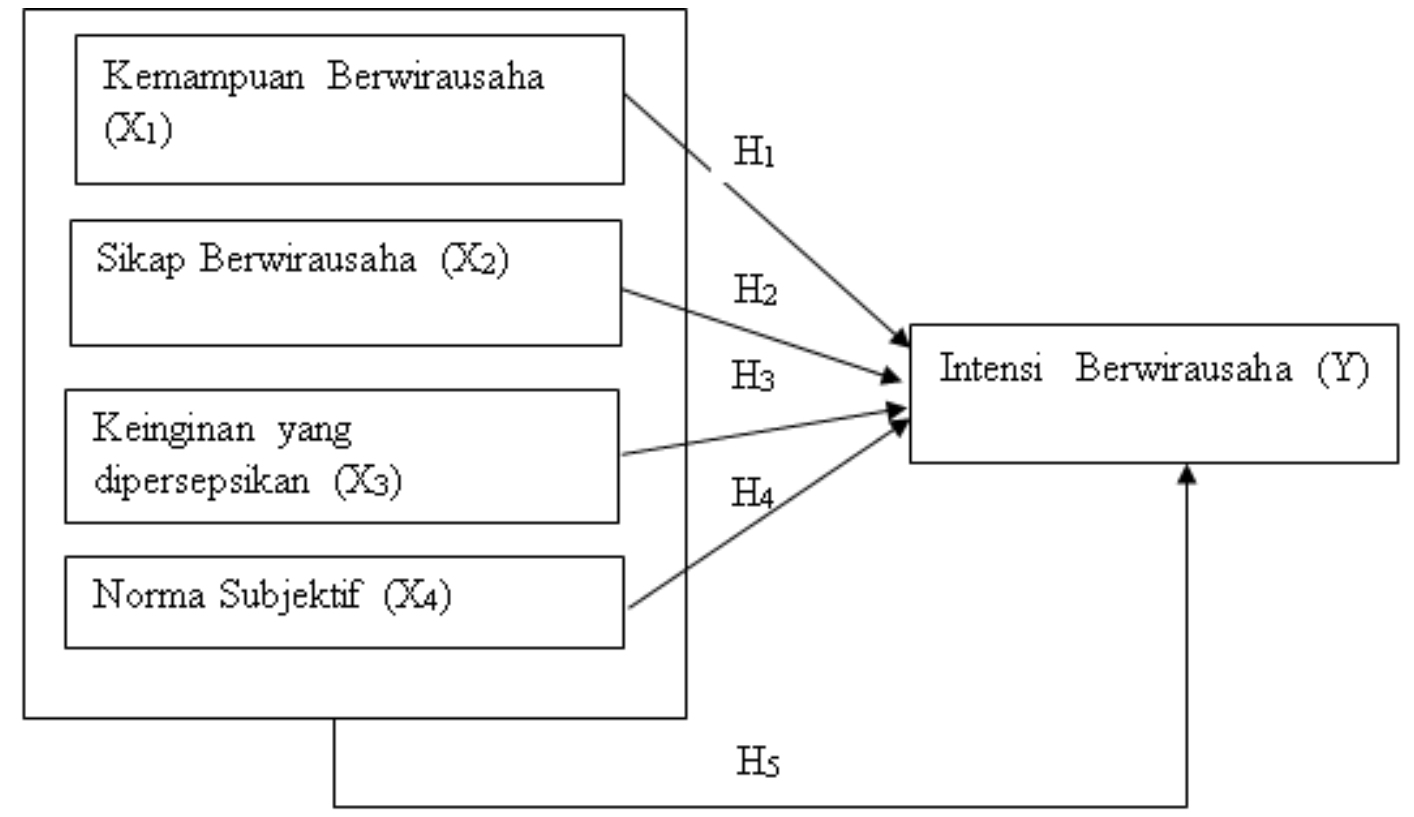

Gambar 1. Kerangka pemikiran

Berdasarkan kerangka pemikiran yang menjelaskan keterkaitan antara variabel yang diteliti, maka hipotesis penelitian ini adalah sebagai berikut:

H1: Terdapat pengaruh kemampuan berwirausaha terhadap intensi berwirausaha.

H2: $\quad$ Terdapat pengaruh sikap berwirausaha terhadap intensi berwirausaha.

H3: Terdapat pengaruh keinginan yang dipersepsikan terhadap intensi berwirausaha.

H4: Terdapat pengaruh norma subjektif terhadap intensi berwirausaha.

H5: Terdapat pengaruh kemampuan berwirausaha, sikap berwirausaha, keinginan yang dipersepsikan dan norma subjektif terhadap intensi berwirausaha. 


\section{METODE PENELITIAN}

Subyek penelitian ini adalah mahasiswa Fakultas Ekonomi dan Bisnis, Universitas Tarumanagara. Penelitian ini merupakan penelitian yang bersifat kuantitatif kausal dan didesain untuk menguji kebenaran empiris antara dua atau lebih variabel penelitian yang telah dirumuskan dalam hipotesis. Variabel independen yang diteliti berupa kemampuan berwirausaha, sikap berwirausaha, keinginan yang dipersepsikan, dan norma subjektif . Variabel dependen dalam penelitian ini adalah intensi berwirausaha. Metode pengumpulan data menggunakan kuesioner dan metode analisis data menggunakan partial least square. Sampel dalam penelitian ini adalah 100 mahasiswa Fakultas Ekonomi dan Bisnis, Universitas Tarumanagara. Tabel 1 menunjukkan butir pernyataan yang digunakan dalam penelitian ini.

Tabel 1. Operasionalisasi variabel

\begin{tabular}{|c|c|c|}
\hline Variabel & Indikator & Skala \\
\hline \multirow{7}{*}{$\begin{array}{l}\text { Kemampuan } \\
\text { Berwirausaha }\end{array}$} & Pengambilan keputusan dengan cepat & \multirow{31}{*}{ Nominal } \\
\hline & Menyukai tantangan & \\
\hline & Menghasilkan produk bermutu & \\
\hline & Kreatif & \\
\hline & Berani mengambil peluang baru & \\
\hline & Tepat waktu dalam menyelesaikan tugas & \\
\hline & Berani mengambil resiko usaha & \\
\hline \multirow{5}{*}{ Sikap Berwirausaha } & $\begin{array}{l}\text { Lebih banyak keuntungan yang diperoleh daripada kerugian dalam menjadi } \\
\text { wirausaha }\end{array}$ & \\
\hline & Karir sebagai wirausaha sangat menarik & \\
\hline & Sikap terhadap peluang usaha & \\
\hline & Prioritas pilihan wirausaha & \\
\hline & Kepuasan menjadi wirausaha & \\
\hline \multirow{6}{*}{$\begin{array}{l}\text { Keinginan yang } \\
\text { Dipersepsikan }\end{array}$} & Kemauan keras unuk memenuhi kebutuhan hidup & \\
\hline & Keyakinan kuat atas kemampuan diri & \\
\hline & Sikap jujur dan bertanggungjawab & \\
\hline & Keuletan dalam bekerja & \\
\hline & Pemikiran yang kreatif & \\
\hline & Berani mengambil resiko & \\
\hline \multirow{3}{*}{ Norma subjektif } & Persetujuan teman terhadap keputusan untuk memulai bisnis & \\
\hline & Persetujuan keluarga terhadap keputusan untuk memulai bisnis & \\
\hline & Persetujuan kolega terhadap keputusan untuk memulai bisnis & \\
\hline \multirow{10}{*}{ Intensi berwirausaha } & Keinginan menjadi bos & \\
\hline & Keinginan memiliki pekerjaan yang menarik & \\
\hline & Keinginan merubah diri & \\
\hline & Keinginan mengambil keuntungan dari bakat kreatif saya & \\
\hline & Keinginan memproleh uang lebih banyak & \\
\hline & Keinginan mengambil keuntungan dari peluang pasar & \\
\hline & Keinginan mempertahankan tradisi keluarga & \\
\hline & Keinginan meningkatkan status & \\
\hline & Keinginan mengikuti contoh seseorang yang saya kagumi & \\
\hline & Kebutuhan pekerjaan & \\
\hline
\end{tabular}

\section{HASIL DAN PEMBAHASAN}

\section{Uji validitas}

Berdasarkan hasil uji validitas konvergen yang ditampilkan pada Tabel 2, setiap butir pernyataan memiliki nilai loading factor lebih besar atau sama dengan 0,7. Nilai tersebut menyatakan bahwa instrumen penelitian sudah valid secara konvergen. 
Tabel 2. Outer loading

\begin{tabular}{|c|c|c|}
\hline Variabel & Indikator & Outer \\
\hline \multirow{7}{*}{$\begin{array}{l}\text { Kemampuan } \\
\text { Berwirausaha }\end{array}$} & Pengambilan keputusan dengan cepat & 0,722 \\
\hline & Menyukai tantangan & 0,848 \\
\hline & Menghasilkan produk bermutu & 0,764 \\
\hline & Kreatif & 0,756 \\
\hline & Berani mengambil peluang baru & 0,825 \\
\hline & Tepat waktu dalam menyelesaikan tugas & 0,806 \\
\hline & Berani mengambil resiko usaha & 0,765 \\
\hline \multirow{5}{*}{$\begin{array}{l}\text { Sikap } \\
\text { Berwirausaha }\end{array}$} & $\begin{array}{l}\text { Lebih banyak keuntungan yang diperoleh daripada kerugian dalam menjadi } \\
\text { wirausaha }\end{array}$ & 0,813 \\
\hline & Karir sebagai wirausaha sangat menarik & 0,919 \\
\hline & Sikap terhadap peluang usaha & 0,940 \\
\hline & Prioritas pilihan wirausaha & 0,899 \\
\hline & Kepuasan menjadi wirausaha & 0,927 \\
\hline \multirow{6}{*}{$\begin{array}{l}\text { Keinginan yang } \\
\text { Dipersepsikan }\end{array}$} & Kemauan keras unuk memenuhi kebutuhan hidup & 0,920 \\
\hline & Keyakinan kuat atas kemampuan diri & 0,860 \\
\hline & Sikap jujur dan bertanggungjawab & 0,940 \\
\hline & Keuletan dalam bekerja & 0,912 \\
\hline & Pemikiran yang kreatif & 0,912 \\
\hline & Berani mengambil resiko & 0,882 \\
\hline \multirow{3}{*}{ Norma subjektif } & Persetujuan teman terhadap keputusan untuk memulai bisnis & 0,963 \\
\hline & Persetujuan keluarga terhadap keputusan untuk memulai bisnis & 0,951 \\
\hline & Persetujuan kolega terhadap keputusan untuk memulai bisnis & 0,944 \\
\hline \multirow{10}{*}{$\begin{array}{c}\text { Intensi } \\
\text { berwirausaha }\end{array}$} & Keinginan menjadi bos & 0,906 \\
\hline & Keinginan memiliki pekerjaan yang menarik & 0,879 \\
\hline & Keinginan merubah diri & 0,812 \\
\hline & Keinginan mengambil keuntungan dari bakat kreatif saya & 0,895 \\
\hline & Keinginan memproleh uang lebih banyak & 0,890 \\
\hline & Keinginan mengambil keuntungan dari peluang pasar & 0,816 \\
\hline & Keinginan mempertahankan tradisi keluarga & 0,890 \\
\hline & Keinginan meningkatkan status & 0,868 \\
\hline & Keinginan mengikuti contoh seseorang yang saya kagumi & 0,811 \\
\hline & Kebutuhan pekerjaan & 0,889 \\
\hline
\end{tabular}

Berdasarkan uji validitas diskriminan yang ditampilkan pada Tabel 3, setiap variabel memiliki nilai Average Variance Extracted (AVE) lebih besar atau sama dengan 0,5. Nilai tersebut menyatakan bahwa instrumen penelitian sudah valid secara konvergen.

Tabel 3. Average Variance Extracted

\begin{tabular}{|l|l|}
\hline \multicolumn{1}{|c|}{ Variabel } & AVE \\
\hline Kemampuan Berwirausaha & 0,616 \\
\hline Sikap Berwirausaha & 0,811 \\
\hline Keinginan yang Dipersepsikan & 0,819 \\
\hline Norma subjektif & 0,908 \\
\hline Intensi berwirausaha & 0,750 \\
\hline
\end{tabular}




\section{Uji reliabilitas}

Berdasarkan uji reliabilitas yang ditampilkan pada Tabel 4, seluruh nilai Crobach's alpha lebih besar dari 0,6 yang berarti instrumen penelitian atau kuesioner sudah reliabel.

Tabel 4. Cronbach's alpha

\begin{tabular}{|l|c|}
\hline \multicolumn{1}{|c|}{ Variabel } & Cronbach's Alpha \\
\hline Kemampuan Berwirausaha & 0,896 \\
\hline Sikap Berwirausaha & 0,941 \\
\hline Keinginan yang Dipersepsikan & 0,956 \\
\hline Norma subjektif & 0,949 \\
\hline Intensi berwirausaha & 0,941 \\
\hline
\end{tabular}

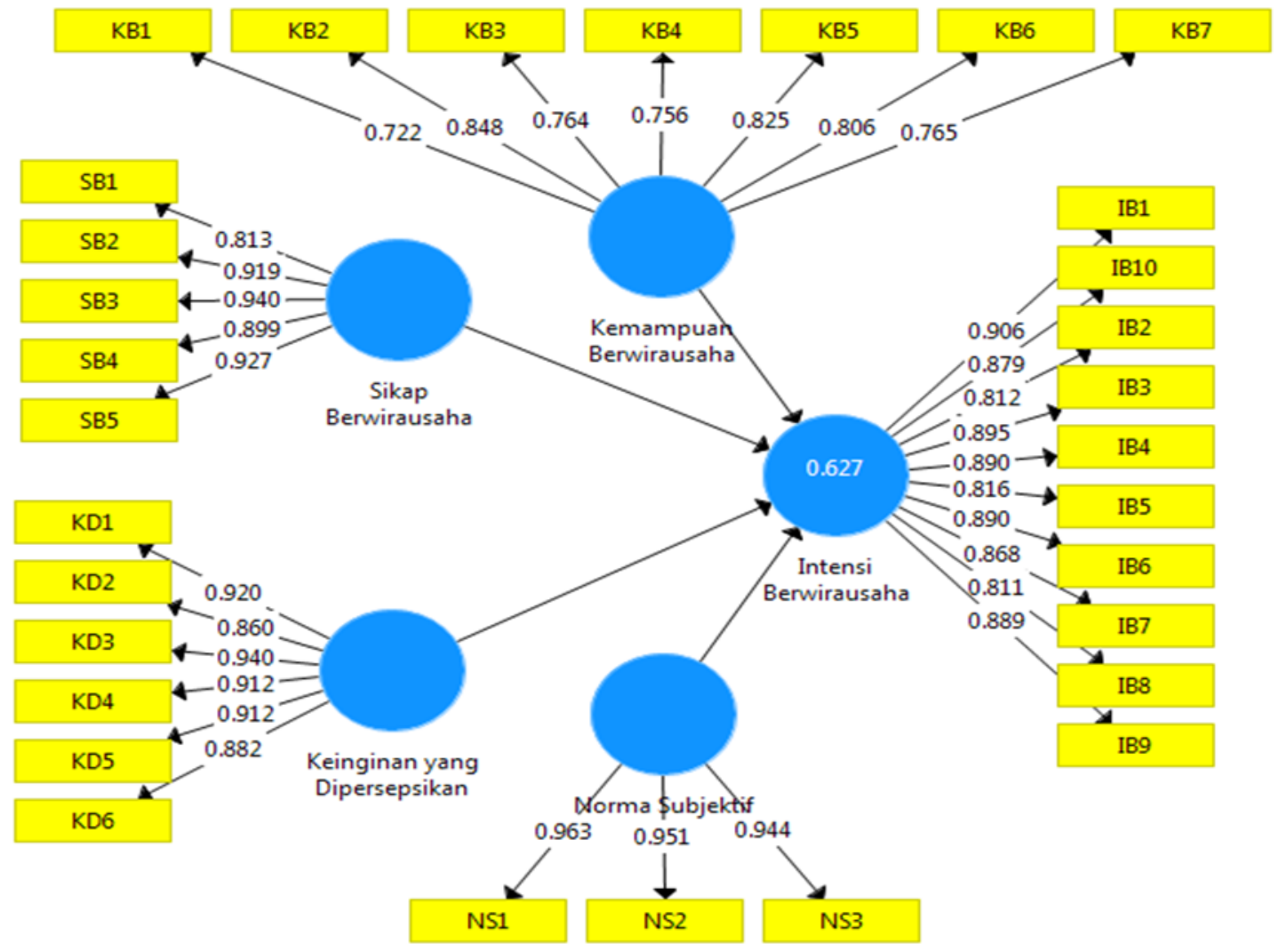

Gambar 2. Outer loading

Tabel 5. Hasil pengujian hipotesis

\begin{tabular}{|l|c|c|c|c|}
\hline \multicolumn{1}{|c|}{ Hipotesis } & Original Sample & $\boldsymbol{t}$-statistic & $\boldsymbol{p}$-values & Evaluasi model \\
\hline $\begin{array}{l}\text { Kemampuan Berwirausaha } \rightarrow \text { Intensi } \\
\text { Berwirausaha }\end{array}$ & $-0,268$ & 2,331 & 0,020 & Signifikan \\
\hline Sikap Berwirausaha $\rightarrow$ Intensi Berwirausaha & 1,045 & 13,030 & 0,000 & Signifikan \\
\hline $\begin{array}{l}\text { Keinginan yang dipersepsikan } \rightarrow \text { Intensi } \\
\text { Berwirausaha }\end{array}$ & $-0,204$ & 2,566 & 0,011 & Signifikan \\
\hline Norma Subjektif $\rightarrow$ Intensi Berwirausaha & 0,103 & 1,053 & 0,293 & Tidak Signifikan \\
\hline
\end{tabular}




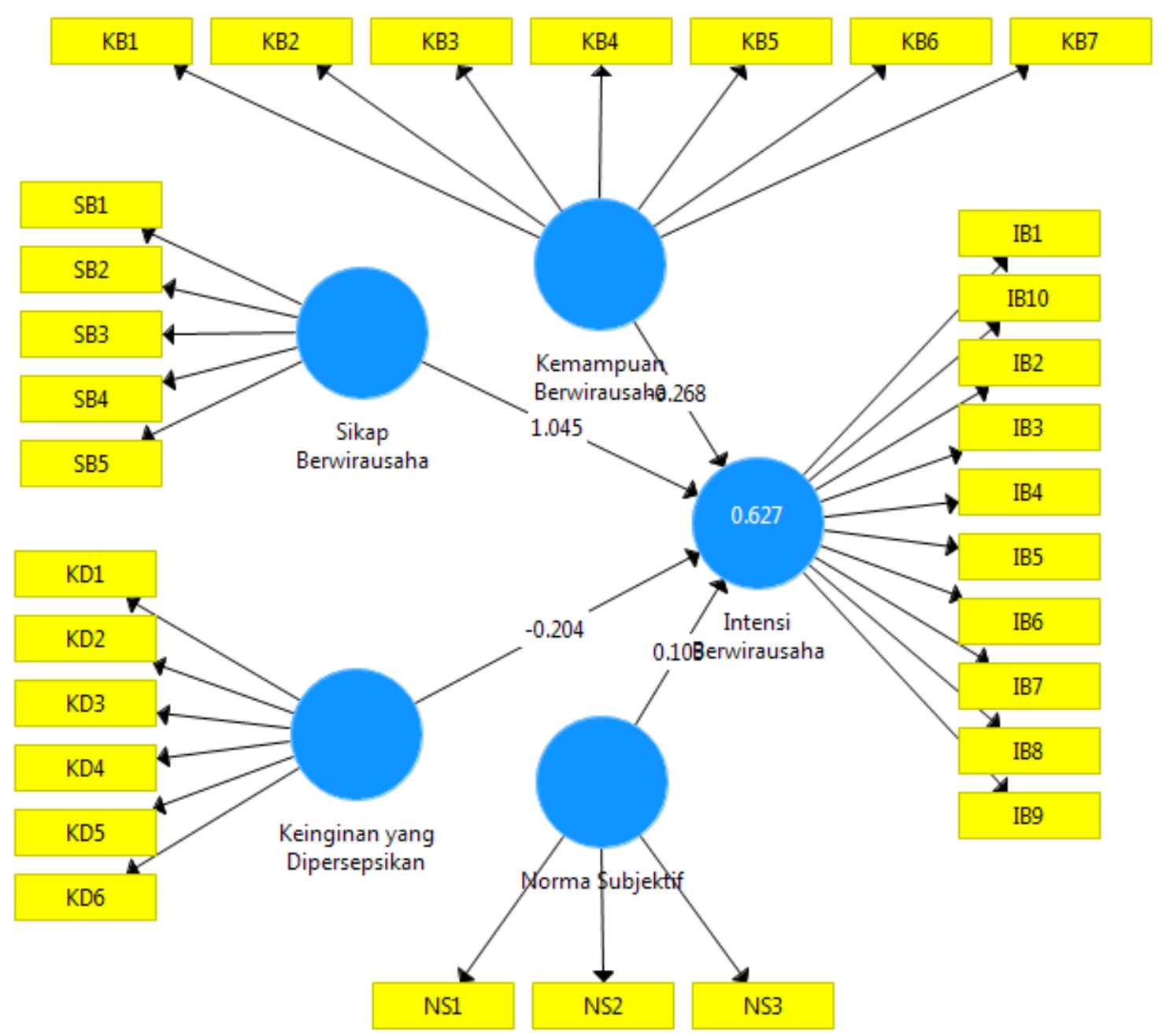

Gambar 3. Path coefficient

\section{Diskusi}

Berdasarkan hasil pengujian hipotesis, diketahui bahwa terdapat pengaruh kemampuan berwirausaha terhadap intensi berwirausaha, terdapat pengaruh sikap berwirausaha terhadap intensi berwirausaha, terdapat pengaruh keinginan yang dipersepsikan terhadap intensi berwirausaha, dan tidak terdapat pengaruh norma subjektif terhadap intensi berwirausaha. Hasil tersebut sesuai dengan penelitian Yousaf et al. (2015), Malebana (2014), dan Robledo et al. (2015). Kemampuan berwirausaha dapat memberikan kepercayaan diri kepada wirausahawan dalam hal mengelola usaha. Kemampuan berwirausaha dapat diperoleh melalui pendidikan dan pengalaman. Menurut Yousaf et al. (2015), wirausahawan yang memiliki kemampuan berwirausaha cenderung memiliki intensi berwirausaha yang tinggi. Oleh karena itu, kemampuan berwirausaha memberikan bekal kepada calon wirausahawan. Sikap menunjukkan tingkatan dimana seseorang mempunyai evaluasi yang baik atau kurang baik. Semakin baik sikap seseorang terhadap wirausaha, maka semakin tinggi intensi berwirausaha yang dimilikinya. Menurut Robledo et al. (2015), sikap berpengaruh terhadap intensi berwirausaha. Wirausaha menumbuhkan sikap yang mendukung keberhasilan berwirausaha. Sikap ini mengevaluasi tindakan yang mendukung dan tidak mendukung terhadap keberhasilan berwirausaha dengan tujuan meningkatkan intensi berwirausaha. 
Keinginan yang dipersepsikan adalah derajat ketertarikan seseorang untuk berwirausaha. Para wirausahawan umumnya memiliki keinginan yang dipersepsikan yang tinggi. Menurut Yousaf et al. (2015), keinginan yang dipersepsikan mempengaruhi intensi kewirausahaan. Keinginan yang dipersepsikan tinggi menggambarkan wirausahawan yang memiliki tingkat ketertarikan yang tinggi dalam berwirausaha. Norma subjektif sebagai pengaruh sosial yang menunjukkan tekanan sosial yang dirasakan untuk melakukan atau tidak melakukan tindakan atau perilaku. Semakin tinggi dukungan dari norma subjektif terhadap kewirausahaan, maka semakin tinggi intensi berwirausaha. Menurut Robledo et al. (2015), norma subjektif berpengaruh terhadap intensi berwirausaha. Pengaruh lingkungan sosial sangat kuat dalam menentukan motivasi seseorang. Lingkungan sosial yang mendukung kewirausahaan dapat meningkatkan intensi berwirausaha.

Wirausahawan yang memiliki kemampuan berwirausaha cenderung memiliki intensi berwirausaha yang tinggi. Sikap mengevaluasi tindakan yang mendukung dan tidak mendukung terhadap keberhasilan berwirausaha dengan tujuan meningkatkan intensi berwirausaha. Keinginan yang dipersepsikan yang tinggi menggambarkan wirausahawan yang memiliki tingkat ketertarikan yang tinggi dalam berwirausaha. Norma subjektif yang mendukung kewirausahaan dapat meningkatkan intensi berwirausaha.

\section{KESIMPULAN DAN SARAN}

Kemampuan berwirausaha dapat memberikan kepercayaan diri kepada wirausahawan dalam hal mengelola usaha. Kemampuan berwirausaha dapat diperoleh melalui pendidikan dan pengalaman. Wirausahawan yang memiliki kemampuan berwirausaha cenderung memiliki intensi berwirausaha yang tinggi. Oleh karena itu, kemampuan berwirausaha memberikan bekal kepada calon wirausahawan.

Sikap menunjukkan tingkatan dimana seseorang mempunyai evaluasi yang baik atau kurang baik. Semakin baik sikap seseorang terhadap wirausaha, maka semakin tinggi intensi berwirausaha yang dimilikinya. Sikap berpengaruh terhadap intensi berwirausaha. Wirausaha menumbuhkan sikap yang mendukung keberhasilan berwirausaha. Sikap ini mengevaluasi tindakan yang mendukung dan tidak mendukung terhadap keberhasilan berwirausaha dengan tujuan meningkatkan intensi berwirausaha.

Keinginan yang dipersepsikan adalah derajat ketertarikan seseorang untuk berwirausaha. Para wirausahawan umumnya memiliki keinginan yang dipersepsikan yang tinggi. Keinginan yang dipersepsikan mempengaruhi intensi kewirausahaan. Keinginan yang dipersepsikan tinggi menggambarkan wirausahawan memiliki tingkat ketertarikan yang tinggi dalam berwirausaha.

Penambahan variabel yang relevan sangat disarankan untuk penelitian selanjutnya agar dapat memberikan kontribusi terhadap penelitian mengenai faktor yang mempengaruhi intensi berwirausaha. Penambahan sampel penelitian dapat memberikan hasil yang berbeda, sehingga dapat memberikan kontribusi penelitian mengenai intensi berwirausaha.

\section{REFERENSI}

Andika, R. dan Yuliana, P. (2017). Pengaruh Kemampuan Berwirausaha dan Kepribadian terhadap Pengembangan Karir Individu pada Member PT. Ifaria Gemilang (IFA) Depot Sumatera Jaya Medan. Jurnal Manajemen Tools, Vol. 8, No. 2. 
Hattab, H. (2014). Impact of Entrepreneurship Education on Entrepreneurial Intention of University Students in Egypt. The Journal of Entrepreneurship, 23(1), 1-18.

Hendrawan, J. S. dan Sirine, H. (2017). Pengaruh Sikap Mandiri, Motivasi, Pengetahuan Kewirausahaan terhadap Minat Berwirausaha. Asian Journal of Innovation and Entrepreneurship, 2(3), 291-314.

Huda, N., Rini, N., Mardoni, Y., Putra, P. (2013). The Analysis of Attitudes, Subjective Norms, and Behavioral Control on Muzakki's Intention to Pay Zakah. International Journal of Business and Social Science, 3(22), 271-279.

Krishna, S. M. (2013). Entrepreneurial Motivation A Case Study of Small Scale Entrepreneurs in Mekelle, Ethiopia. Journal of Business \& Social Sciences Research, 2(1), 1-6.

Malebana, M. J. (2014). Entrepreneurial Intentions and Entrepreneurial Motivation of South African Rural University Students. Journal of Economics and Behavioural Studies, 6(9), 709-726.

Pratana, J. A. J. dan Japarianto, E. (2014). Analisis Pengaruh Sikap, Subjective Norm dan Perceived Behavioural Control terhadap Purchase Intention Pelanggan SOGO Departement Store di Tunjungan Plaza Surabaya. Jurnal Strategi Pemasaran, 2(1), 1-7.

Ranmuthumalie, S. L. (2010). Business Start-up and Growth Motives of Entrepreneurs. Manchaster Business School Working Paper, No. 597.

Retno K. N. (2012). Pengaruh Kemampuan Wirausaha dan Kreativitas terhadap Keberhasilan Usaha pada Restoran Sindang Reret Cabang Surapati Bandung. Jurnal Unikom.

Robledo, J. L. R., Aran, M. V., Martin-Sanchez, V. dan Molina, M. A. R. (2015). The Moderating Role of Gender on Entrepreneurial Intentions: A TPB Perspective. Intangible Capital, Vol. 11, No. 1, Hal. 92-117.

Susanti, Y. dan Gunarsih, T. (2008). Pengaruh Sikap terhadap Perilaku, Faktor Sosial dan Kontrol Keperilakuan yang Dirasakan terhadap Minat Pembeliaan Tiket Pesawat Secara Online. National Conference on Management Research 2008.

Ustha, E. (2018). Analisis Faktor-Faktor yang Memotivasi Mahasiswa Berkeinginan Menjadi Wirausaha di Pekanbaru (Studi Kasus pada Empat Universitas di Pekanbaru). Tansiq: Jurnal Manajemen dan Bisnis Islam, 1(2), 138-157.

Yogatama, L. A. M. (2013). Analisis Pengaruh Attitude, Subjective Norm, dan Perceived Behaviour Control terhadap Intensi Penggunaan Helm Saat Mengendarai Motor pada Remaja dan Dewasa Muda di Jakarta Selatan. Proceeding PESAT, Vol. 5.

Widjaya, O. H., Riswanto, R., dan Suryawan, I. N. (2014). Pengaruh Management Skill, Financial Investor, dan Human Capital terhadap Woman Entrepreneurial Success. Jurnal Bisnis dan Akuntansi, 16(1), 21-26.

\& Ekawati, S. (2017). Faktor Internal Sebagai Penentu Niat Mahasiswa untuk Berwirausaha. Jurnal Muara Ilmu Ekonomi dan Bisnis, 1(2), 24-32.

Yousaf, U, Shamim, A., Siddiqui, H., dan Raina, M. (2015). Studying the Influence of Entrepreneurial Attributes, Subjective Norms and Perceived Desirability on Entrepreneurial Intentions. Journal of Entrepreneurship in Emerging Economics, 7(1), 2334. 